\title{
IMPLEMENTASI DESAIN FASILITAS UMUM DARI HASIL ANALISA TAPAK PADA LINGKUNGAN KOMPLEK SIDOMAKMUR BARU
}

\author{
Bayu Teguh Ujianto \\ Dosen Prodi Arsitektur, Fak. Teknik Sipil dan Perencanaan, ITN Malang \\ e-mail: bayu teguh@lecturer.itn.ac.id \\ Redi Sigit Febrianto \\ Dosen Prodi Arsitektur, Fak. Teknik Sipil dan Perencanaan, ITN Malang \\ e-mail: redi sigit@lecturer.itn.ac.id
}

\begin{abstract}
ABSTRAK
Keberadaan fasilitas umum sangat dibutuhkan pada komplek permukiman pada umumnya, terutama di J. Sidomakmur Baru, karena hal tersebut merupakan kelengkapan dasar fisik lingkungan yang memungkinkan lingkungan dapat berfungsi sebagaimana mestinya. Perancangan fasilitas umum di Jl. Sidomakmur Baru ini, diharapkan mampu memberikan konstribusi yang nyata kepada warga, mengingat kurangnya fasilitas umum tersebut memiliki kendala tersendiri bagi penghuni kavling tersebut. Terutama pada area gerbang masuk komplek kavling tersebut. Dalam perancangan ini, akan dihasilkan sebuah produk berupa desain signage, pos jaga dan taman pengarah yang merupakan program lanjutan warga kavling yang rencananya akan segera direalisasikan. Desain analisa perancangan fasilitas umum kompleks kavling Sidomakmur Baru terbagi menjadi beberapa area yaitu Area $A$ (Signage, Pos Jaga dan Taman Pengarah), area B (Pagar Pembatas), area $C$ (Balai Warga), area D (Taman Bermain dan Berkumpul). Metode pendekatan yang digunakan antara lain metode diskusi dan sosialisasi, metode observasi dan analisis data, serta metode partisipasi sosial. Pendekatan tersebut diharapkan mampu merangkul semua pihak terkait untuk bekerjasama mewujudkan program kegiatan ini.
\end{abstract}

\section{Kata kunci : Signage, Pos Jaga, Taman Pengarah, Fasilitas Umum}

\begin{abstract}
The existence of public facilities is needed in the residential complex in general, especially on Jl. Sidomakmur Baru, because it is a basic completeness of the physical environment that allows the environment to function as it should. Designing public facilities on Jl. New Sidomakmur is expected to be able to make a real contribution to the residents, given the lack of public facilities has its own constraints for the residents of the lots. Especially in the entrance area of the lot complex. In this design, a product will be produced in the form of signage designs, guard posts and a referral park which is an advanced program of land plots which is planned to be realized soon. The design analysis of the design of the Sidomakmur Baru complex complex public facilities is divided into several areas, namely Area
\end{abstract}


A (Signage, Guard Post and Steering Park), area B (Guardrail), area $C$ (Community Hall), area D (Play and Gathering).

Approach methods used include discussion and outreach methods, methods of observation and data analysis, and methods of social participation. The approach is expected to be able to embrace all relevant parties to work together to realize this program of activities.

\section{Keywords : Signage, Guardhouse, Steering Park, Public Facilities}

\section{PENDAHULUAN}

Sarana dan prasarana lingkungan merupakan kebutuhan dasar dan merupakan faktor penting dalam peningkatan stabilitas sosial, dinamika dan produktifitas masyarakat. Dengan membantu proses desain fasilitas umum masyarakat maka akan membantu mewujudkan lingkungan yang sehat, bersih dan nyaman. Oleh karena itu, diharapkan desain perancangan yang dihasilkan mampu dibangun dan diterapkan dengan baik oleh warga.

Saat ini jumlah Kavling pada Komplek Kavling Sidomakmur Baru ini berjumlah 39 kavling dan telah terbangun 24 rumah dengan 24 Kepala Keluarga. Permasalahan yang dihadapi warga Komplek Kavling Sidomakmur Baru saat ini adalah kurangnya fasilitas umum yang memadai. Oleh karena itu, kegiatan Pra-Desain Area Gerbang Masuk Komplek Kavling Sidomakmur Baru ini, merupakan kegiatan lanjutan dari program perancangan sebelumnya yaitu berupa analisa dan konsep tapak. Dari hasil analisa tersebut dapat dikerucutkan fasum apa saja yang akan di desain dan diterapkan pada area gerbang masuk antara lain adalah Signage, Pos Jaga dan Taman pengarah (Area A). Dalam kegiatan perancangan ini, area desain gerbang masuk yang nantinya berupa produk perancangan yang diharapkan dapat diterapkan pada komplek kavling Sidomakmur Baru.

Kegiatan perancangan fasilitas umum berupa desain area gerbang masuk kawasan yang berupa signage, pos jaga, dan taman pengarah tersebut, selain yang telah dijabarkan diatas juga bertujuan untuk:

a. Meningkatkan partisipasi dan mengembangkan swadaya masyarakat dalam bidang pembangunan.

b. Menumbuhkan dan meningkatkan semangat gotong royong

c. Meningkatkan fasilitas umum warga.

d. Membentuk kondisi lingkungan yang aman dan nyaman untuk digunakan beraktifitas warga sehari-hari.

Gambar produk perancangan fasilitas umum nantinya dapat dijadikan sebagai acuan bagi warga Komplek Kavling untuk membangun desain area gerbang masuk kawasan antara lain berupa signage, pos jaga dan taman

PAWON: Jurnal Arsitektur, Nomor 01 Volume IV, Bulan Januari-Juni Tahun 2020, ISSN 2597-7636 
pengarah yang baik dari segi pemanfaatan dan keindahan serta sebagai acuan bagi warga Komplek Kavling Sidomakmur Baru. Penerapan ilmu Arsitektur ini akan sangat membantu warga Komplek Kavling tersebut dalam mencapai estetika sebuah bentuk dan fungsinya.

\section{TINJAUAN PUSTAKA}

Program pendampingan ini merupakan program lanjutan dari hasil program pendampingan sebelumnya. Berdasarkan permasalahan dan uraian dari program pendampingan sebelumnya bahwa telah diperoleh hasil musyawarah secara mufakat bersama warga bahwa yang akan dibangun segera dan merupakan tahap awal adalah desain area gerbang masuk kawasan yang antara lain adalah sebagai berikut:

\subsection{Desain Signage}

Menurut Pierce, sign sebagai segala sesuatu yang mampu mewakili sesuatu yang lain. Sedangkan menurut Christianna Signage adalah bentuk komunikasi yang kini sangat dibutuhkan sebagai suatu sarana informasi. Ide desain Signage ini, diperlukan untuk menjawab permasalahan mengenai identitas wilayah terkait Mitra 2 warga Komplek Kavling Sidomakmur Baru dan permasalahan yang muncul karena tidak adanya identitas komplek kavling. Berdasarkan pada hasil diskusi antara tim pengusul dan mitra maka disepakai bahwa Signage yang akan diterapkan adalah gapura yang mampu mewakili identitas wilayah dan kepribadian warga Komplek Kavling Sidomakmur Baru yang mampu dicerna dan dipahami oleh warga sekitarnya.

Menurut Kusrianto $(2010,23)$ signage adalah sejenis visual grafis dalam ukuran besar yang dibuat untuk menyampaikan informasi pada kalangan audience tertentu. Signage sebelumnya dikenal dalam bentuk tanda (sign) atau dalam bentuk aksara, seperti petunjuk arah tempat, nama suatu tempat dan sebagainya. Sedangkan menurut Supriyanto (2008: 55) signage merupakan media luar ruang yang wujudnya berbentuk tugu atau monumen kecil yang menyatu dengan lingkungan yang ditempatinya.

Berkaitan dengan lingkungan, Rubenstein (1996: 141) mendefinisikan bahwa signage merupakan sistem tanda bagian dari bidang komunikasi visual yang berfungsi sebagai sarana informasi dan komunikasi secara arsitektural. Dengan demikian, dapat disimpulkan bahwa signage adalah media komunikasi visual lingkungan yang menginformasikan pesan secara cerdik melaui integrasi bahasa visual dengan lingkungannya.

Oleh sebab itu dalam mendesain signage yang merupakan sebuah tanda harus mudah dikenali, dibaca, akurat, dapat dipercaya, terdesain dengan baik dan memiliki informasi yang tepat pada tempat yang tepat pula.

PAWON: Jurnal Arsitektur, Nomor 01 Volume IV, Bulan Januari-Juni Tahun 2020, ISSN 2597-7636 
Signage harus mampu menghadirkan informasi melalui sebuah sistem yang saling berhubungan satu sama lain dimana di dalamnya menggabungkan antara pesan dan pola lalu lintas kemudian menyatukan keduanya dengan lingkungannya terutama dalam segi arsitektur.

\subsection{Desain Pos Jaga}

Menurut kamus besar bahasa Indonesia gardu yakni berarti rumah jaga (tempat berkawal); rumah kecil di tepi jalan; depot. Pos diartikan sebagai tempat surat, tempat kedudukan atau jabatan, tempat penjagaan, gardu penjagaan, tempat pemberhentian tiang, dan jenang pintu. Ronda diartikan sebagai aktifitas jaga atau patroli. Dengan demikian gardu pos ronda merupakan bangunan arsitektural sebagai tempat berhentinya, bertemu, atau berkumpulnya para petugas jaga keamanan.

Pos Jaga yang nantinya akan dibangun pada komplek kavling Sidomakmur Baru ini merupakan tempat penjagaan dari ancaman maling dan keamanan wilayah dan juga sebagai tempat kerja satpam tersebut. Untuk letak dan posisi yang nantinya akan dibangun ditentukan dari hasil analisa tapak pada program pengabdian masyarakat yang telah dilakukan sebelumnya. Hal tersebut dimaksudkan agar letak pos jaga yang akan dibangun tepat guna dan tepat sasaran dalam proses perancangannya.

\subsection{Desain Taman}

Secara psikologis, tanaman dapat berfungsi sebagai pengarah bila ditanam pada jarak dan pola tertentu. Permainan tekstur, keindahan bunga dan hijaunya daun pada tanaman di sepanjang jalan dapat menciptakan suasana santai, nyaman, teduh dan segar. Taman merupakan wajah dan karakter bahan atau tapak yang dapat dinikmati dalam dua karakter, yaitu penampakan visual, dalam arti bisa dilihat, dan penampakan karakter, dalam arti apa yang tersirat dari taman tersebut. Taman yang nantinya akan dirancang berupa taman yang dapat menjadi penunjuk arah dan dapat mengarahkan gerak kegiatan di sebuah lingkungan.

Laurie (1986) mengemukakan bahwa asal mula pengertian kata taman (garden) dapat ditelusuri pada bahasa Ibrani gan, yang berarti melindungi dan mempertahankan; menyatakan secara tidak langsung hal pemagaran atau lahan berpagar, dan oden atau eden, yang berarti kesenangan atau kegembiraan. Jadi dalam bahasa Inggris perkataan "garden" memiliki gabungan dari kedua kata-kata tersebut, yang berarti sebidang lahan berpagar yang digunakan untuk kesenangan dan kegembiraan. Sedangkan menurut Djamal (2005), taman adalah sebidang tanah terbuka dengan luasan tertentu di dalamnya ditanam pepohonan, perdu, semak dan rerumputan yang

PAWON: Jurnal Arsitektur, Nomor 01 Volume IV, Bulan Januari-Juni Tahun 2020, ISSN 2597-7636 
dapat dikombinasikan dengan kreasi dari bahan lainnya. Umumnya dipergunakan untuk olah raga, bersantai, bermain dan sebagainya

Ide desain tersebut diatas, nantinya akan dilakukan dengan bekerjasama dengan berbagai mitra terkait yang turut mendukung perancangan ini.

\section{METODE PENELITIAN}

Metode pendekatan yang digunakan untuk menyelesaikan perancangan ini adalah Metode pendekatan diskusi digunakan pada saat sosialisasi tahap awal kegiatan untuk mendapatkan kesepakatan bersama mengenai ide, lokasi dan konsep terkait rencana perancangan ini. Tahap diskusi selanjutnya dilakukan pada saat penyusunan konsep dan desain rancangan berdasarkan data yang di peroleh, kemudian tahap diskusi selanjutnya dilakukan pada saat sosialisasi produk desain ke warga sehingga didapatkan masukan jika ada tambahan ide yang dapat ditambahkan.

Metode observasi dan analisis data ini digunakan untuk merencanakan dan membuat konsep desain. Observasi lapangan diperlukan untuk mengetahui data dan kondisi eksisting lokasi penempatan lampu jalan, pos satpam dan saluran pembuangan air. Observasi data terkait yang akan digunakan untuk dianalisis oleh tim pengusul dan mitra sebagai dasar untuk menentukan konsep dan desain sarana prasarana di Komplek Kavling Sidomakmur Baru.

Metode pendekatan partisipasi ini dilakukan untuk memberdayakan potensi warga. Hal ini dilakukan untuk tetap menjaga karakter kegotongroyongan warga. Pendekatan partisipasi ini dilaksanakan pada saat proses pengadaan dan pembuatan sarana dan prasarana.

\section{HASIL DAN PEMBAHASAN}

Analisa perancangan fasilitas umum kompleks kavling Sidomakmur Baru ini, akan dibagi menjadi beberapa Area yaitu Area A (Sign in, Pos Jaga dan Taman), Area B (Pagar Pembatas), Area C (Balai Warga), Area D (Taman Bermain dan Berkumpul). Berikut ini adalah pembahasan analisa perancangan fasilitas umum kompleks Sidomakmur Baru. 


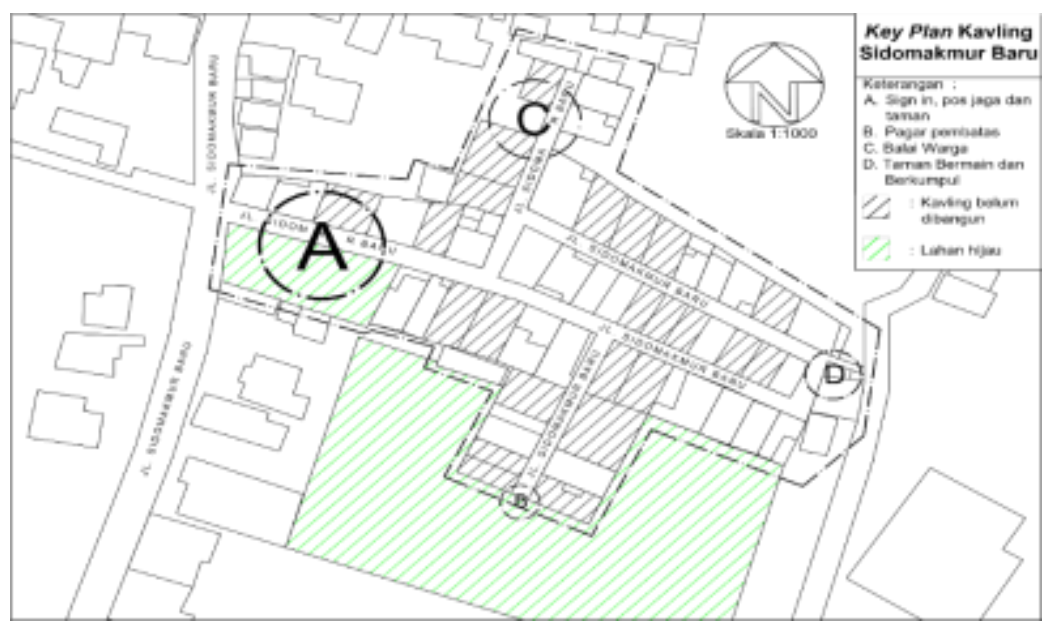

Gambar. 1

Key Plan Kavling Sidomakmur Baru

Sumber: Ujianto, 2019

\subsection{Pra-Desain Sign in}

Dibawah ini merupakan kondisi eksisting analisa Area A, yang merupakan daerah pintu masuk kompleks kavling yang nantinya akan dibangun.

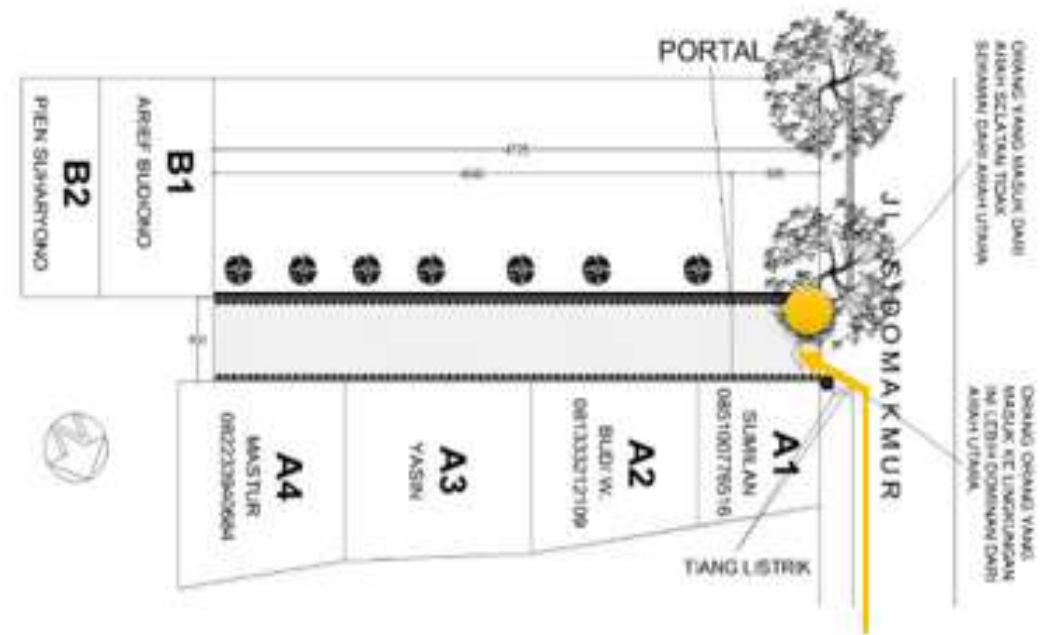

Gambar. 2

Aksebilitas Tapak Area A

Sumber: Ujianto, 2019

PAWON: Jurnal Arsitektur, Nomor 01 Volume IV, Bulan Januari-Juni Tahun 2020, ISSN 2597-7636 
Berdasarkan analisa aksebilitas yang telah dilakukan sebelumnya, didapatkan bahwa lokasi penempatan Sign In tersebut lebih cocok dan tepat jika diterpakan pada sisi bagian SELATAN. Hal tersebut didapatkan karena akses kendaraan dan pejalan kaki lebih dominan masuk dari arah UTARA.

\section{a. Alternatif 1 Sign in}
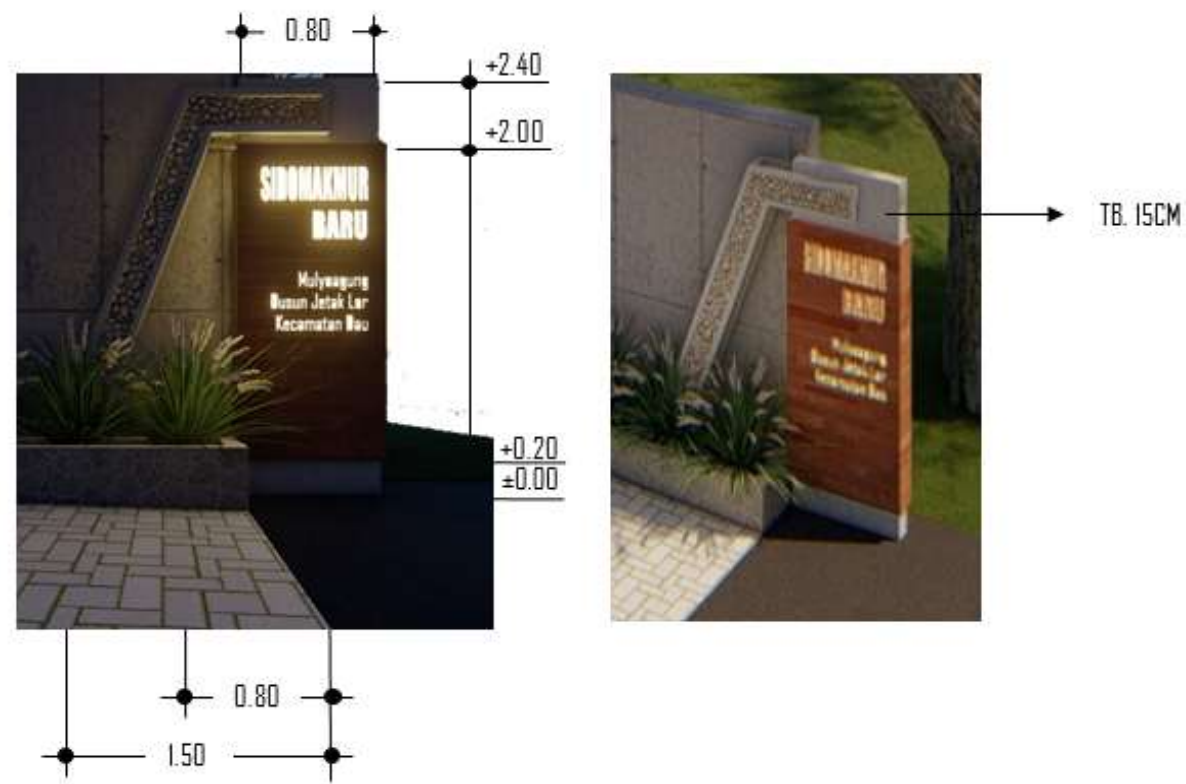

Gambar. 3

Pra-Desain Sign in Alternatif 1

Sumber: Ujianto, 2019

Sign in atau papan nama pada rancangan ini terdiri dari 2 elemen, yaitu; elemen penyangga dan nameboard itu sendiri, keduanya terdiri dari material yang berbeda-beda. Sign in pada tapak memiliki permasalahan tangkapan pandangan, sebab terhalang tiang listrik bila dilihat dari arah utara dan terhalang pohon bila dilihat dari arah selatan. Oleh sebab itu Sign in akan lebih tepat jika ditempatkan dibagian depan jalan Sidomakmur Baru, tepatnya disisi selatan. Hal ini dimaksudkan untuk memberikan identitas pada lingkungan ini.dan memudahkan orang-orang untuk membaca sign in ini.

Maka solusi nya yaitu dengan meletakkan Sign in menjorok ke jalan dan memberikan penerangan tepat pada tulisan, sehingga lebih mudah ditangkap oleh pengendara yang melintas.

\section{b. Alternatif 2 Sign in}

PAWON: Jurnal Arsitektur, Nomor 01 Volume IV, Bulan Januari-Juni Tahun 2020, ISSN 2597-7636 
Papan nama Sidomakmur Baru mengusung tema modern dengan bentuk 2 persegi panjang yang menyatu pada bagian belakang sebagai tiang atau penopang, dan bagian depan persegi panjang untuk penempatan papan nama dengan tulisan yang menjorok ke dalam serta lampu didalamnya, sehingga tulisan terlihat menyala pada malam hari.
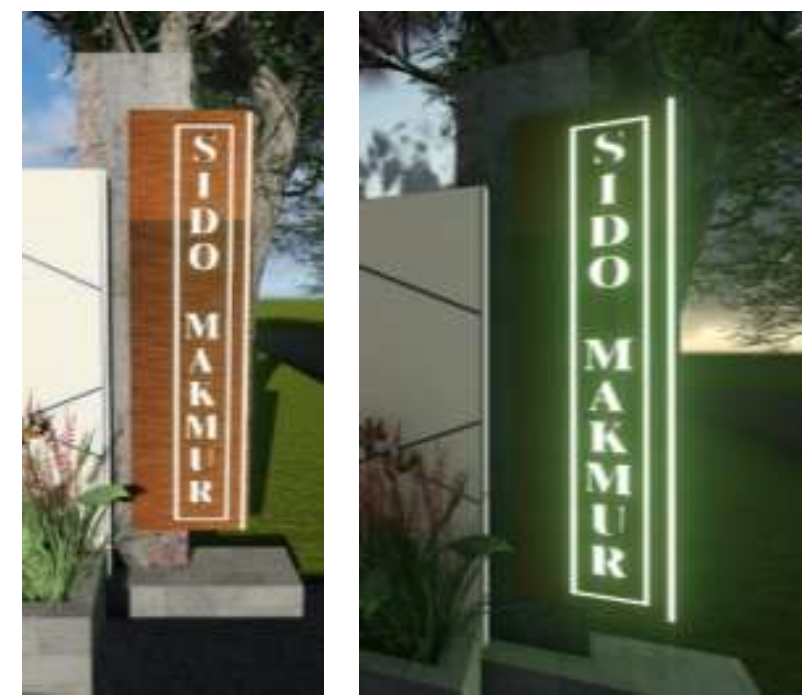

Gambar. 4

Pra-Desain Sign in Alternatif 2

Sumber: Ujianto, 2019
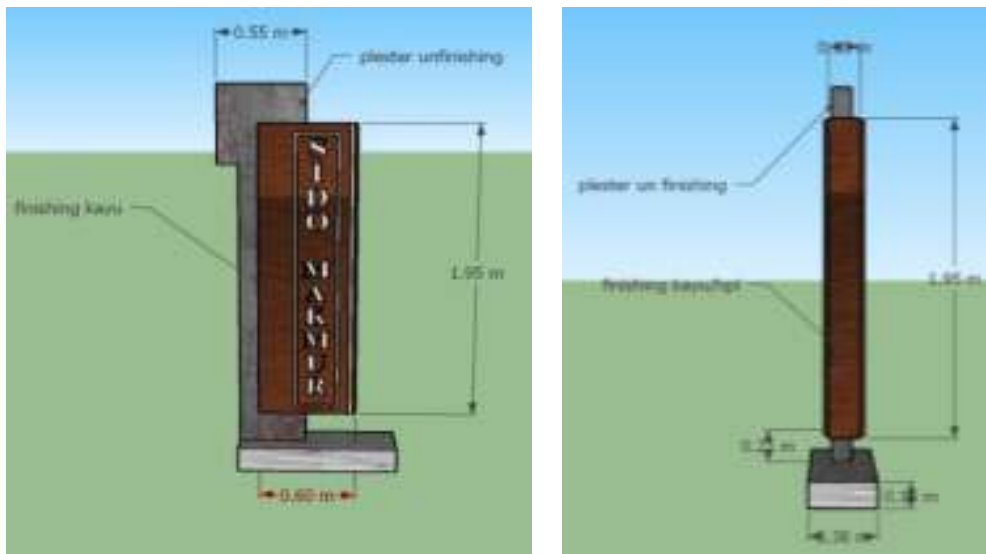

Gambar. 5

Detail Ukuran Pra-Desain Sign in Alternatif 2

Sumber: Ujianto, 2019

Sign in atau papan nama pada rancangan ini terdiri dari 2 bagian yang menyatu, pada bagian belakang persegi panjang dengan material beton 
sebagai tiang atau penopang, serta pada bagian depan persegi panjang dengan rangka besi hollow dengan penutup acrylic putih susu dengan lampu didalamnya serta bagian depan menggunakan triplek $9 \mathrm{~mm}$ cutting pada bagian huruf dengan finishing hpl. Sama halnya yang diterapkan pada alternatif pertama, maka solusi nya yaitu dengan meletakkan Sign in menjorok ke jalan dan memberikan penerangan tepat pada tulisan, sehingga lebih mudah ditangkap oleh pengendara yang melintas.

\subsection{Pra-Desain Pos Jaga}

Kendaraan yang masuk dari arah utara membutuhkan haluan yang cukup karena adanya tiang listrik dan pohon pada sudut kanan jalan Sidomakmur Baru. Sedangkan kendaraan yang masuk dari arah selatan akan terhalangi penglihatannya oleh pohon yang cukup besar serta plengsengan lahan kosong yang ada disamping jalan Sidomakmur Baru dan apabila portal dibuka, membutuhkan space sekitar 5 meter yang mengarah kedalam/ timur Jl. Sidomakmur Baru.

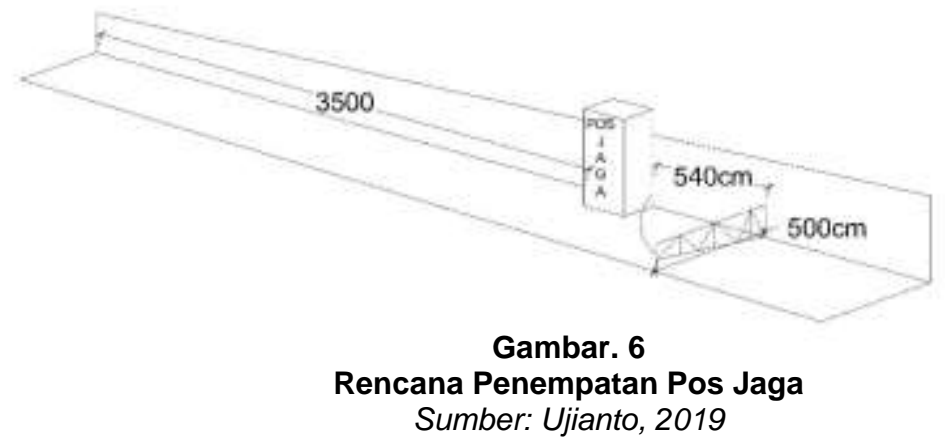

Berdasarkann analisa yang dilakukan sebelumnya, maka Pos Jaga akan lebih tepat berada di sisi selatan dan berada 5,4 meter ke arah timur dari portal (titik akhir pos jaga berada pada jarak 35 meter dari rumah Kav. B). Dengan letak Pos Jaga yang agak menjorok ke dalam, memungkinkan pihak keamanan untuk memantau kendaraan yang akan masuk dari kejauhan.

Arah hadap Pos Jaga berada di arah barat, hal tersebut dimaksudkan untuk memberikan tangkapan pada bangunan Pos Jaga ini. Patahan pada atap yang tadinya berada ditengah akan didorong kearah barat sehingga lebih condong ke arah barat. Maka dengan demikian bangunan ini nantinya akan menghadap kearah barat walaupun entrance berada disisi timur. Dan nantinya akan ada permainan finishing sebagai nilai tambah pada sisi barat sebagai point of interest tersendiri. 


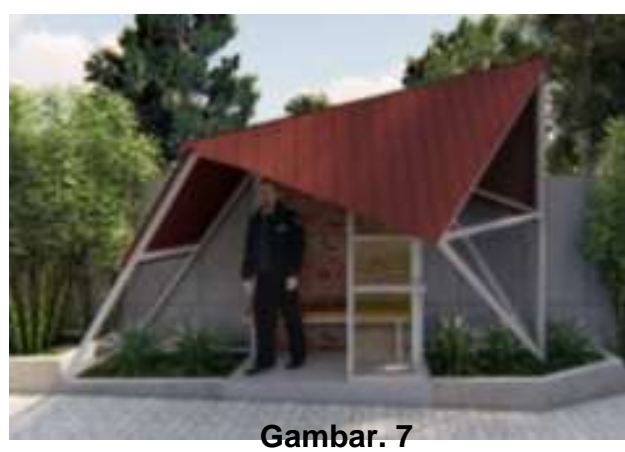

Tampak Depan Pra-Desain Pos Jaga

Sumber: Ujianto, 2019

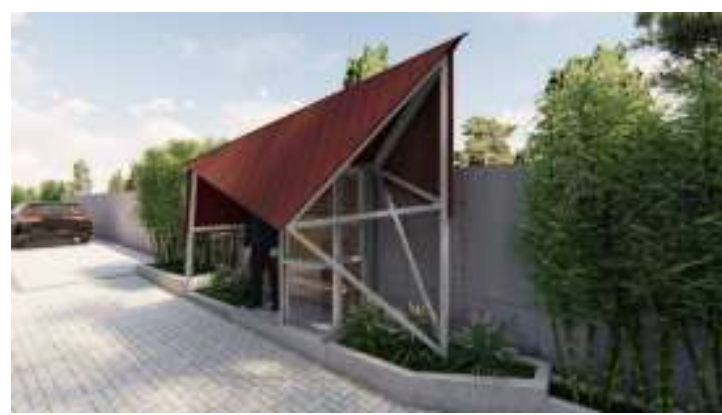

Gambar. 8

Tampak Samping Pra-Desain Pos Jaga

Sumber: Ujianto, 2019

Pos jaga memiliki ukuran $1.00 \times 5.00$ dengan tinggi $3.00 \mathrm{~m}$ dengan bentuk atap asimetris yang berbentuk unik namun fungsional.

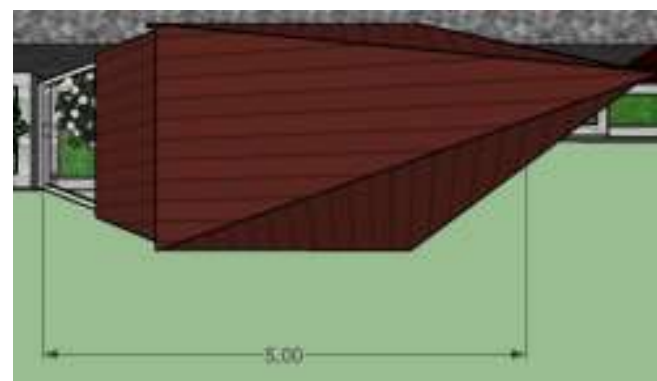

Gambar. 9

Ukuran Pra-Desain Pos Jaga

Sumber: Ujianto, 2019 
Penerapan material yang digunakan pada desain Pos Jaga menggunakan material yang mudah dicari dan diterapkan serta tidak mengeluarkan banyak biaya.

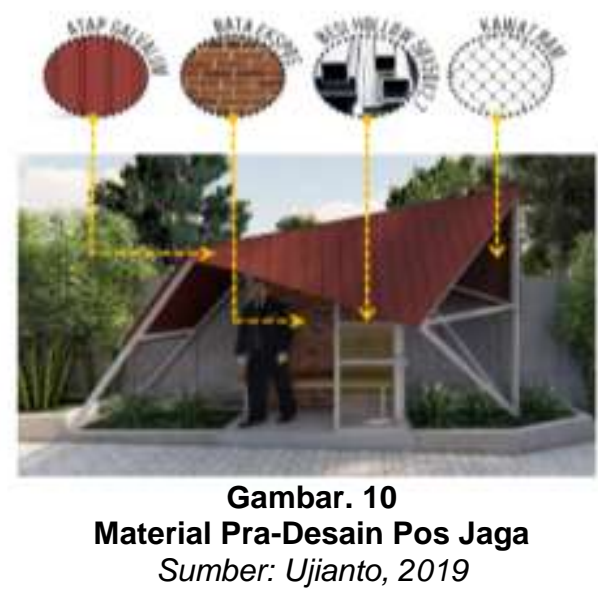

Material pos jaga menggunakan penutup atap galvalum dengan rangka besi hollow 4x4 penutup pada bagian kanan dan kiri dinding menggunakan kawat ayam bagian luar dan pada bagian dalam sisi kanan dinding menggunakan rangka alumunium dengan kaca. Dinding belakang pos jaga dipermanis dengan menggunkan bata merah expose sehingga terlihat menyatu dengan warna atap.

Pada sisi timur Pos Jaga membutuhkan overstek yang cukup untuk meminimalisir sinar matahari langsung dari arah timur pada sisi barat juga diberikan overstek yang cukup. Bentuk atap didesain sedemikian rupa, hal tersebut dikarenakan atap Pos Jaga harus mampu meminimalisir panas matahari yang datang sehingga tetap bisa mempertahankan suhu yang nyaman bagi pengguna Pos Jaga.

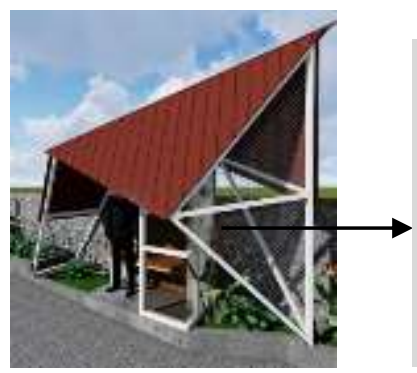

Bukaan pada area barat akan memanfaatkan atap sebagai tempat masuknya angin, ini dilakukan mengingat pada dinding sebelah barat akan dimanfaatkan sebagai pencahayaan dan view from site.

Gambar. 11

Bukaan Pra-Desain Pos Jaga

Sumber: Ujianto, 2019

PAWON: Jurnal Arsitektur, Nomor 01 Volume IV, Bulan Januari-Juni Tahun 2020, ISSN 2597-7636 


\subsection{Taman Pengarah}

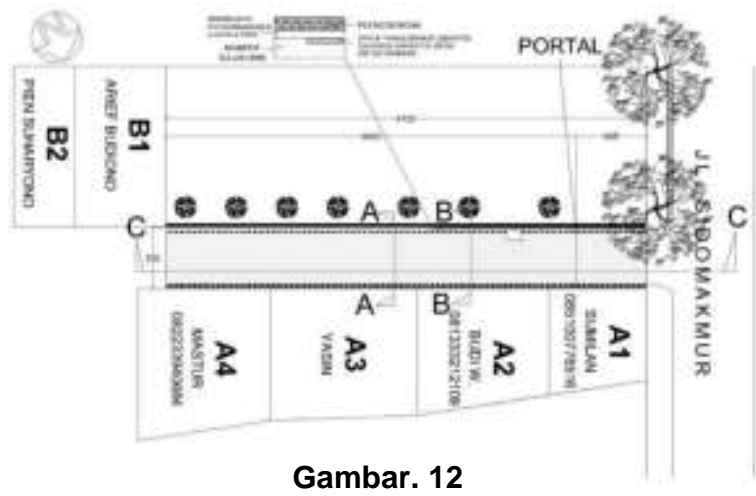

Key Plan Vegetasi

Sumber: Ujianto, 2019

Untuk lahan bagian timur mulai dari ujung tanah Kav.B1 sampai titik 26.5meter ditemui selokan yang nantinya akan ditutup sepenuhnya menggunakan tanah gembur dan kemudian diberi rumput gajah mini. Sehingga, nantinya akan ditanam tanaman pengarah berukuran besar dan kecil. Selokan ini ditutup karena tidak berfungsi secara maksimal.

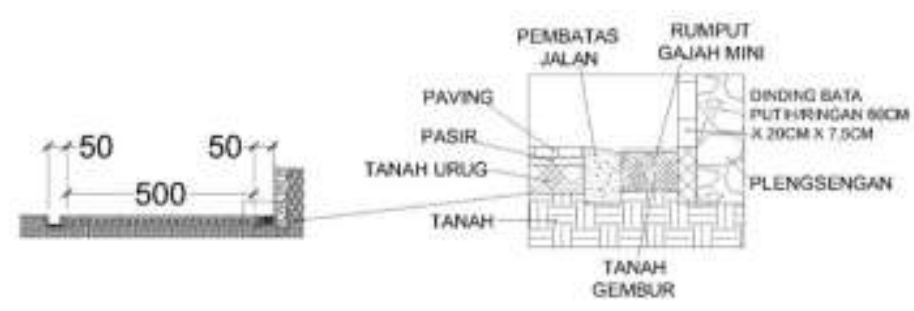

Gambar. 13

Potongan Selokan Yang Tidak Berfungsi Dengan Baik Sumber: Ujianto, 2019

Pada titik 26.5meter dari Kav.B1 sampai ujung barat jalan Sidomakmur Baru, kemiringan topografinya membuat sistem drainase berfungsi secara maksimal karena arah pembuangannya akan kearah sistem drainase kota yang berada di sisi Jl. Sidomakmur. Sehingga, mulai dari titik itu, selokan yang tadi sepenuhnya ditutup dengan tanah gembur dan ditanami rumput gajah mini dengan lebar $30 \mathrm{~cm}$, akan di diperkecil menjadi $23 \mathrm{~cm}$. Dan lebar sisa 7 $\mathrm{cm}$ tadi akan dijadikan sebagai selokan/sistem pembuangan. Space ini hanya diberi kedalaman $5 \mathrm{~cm}$ tanpa finishing apapun. 


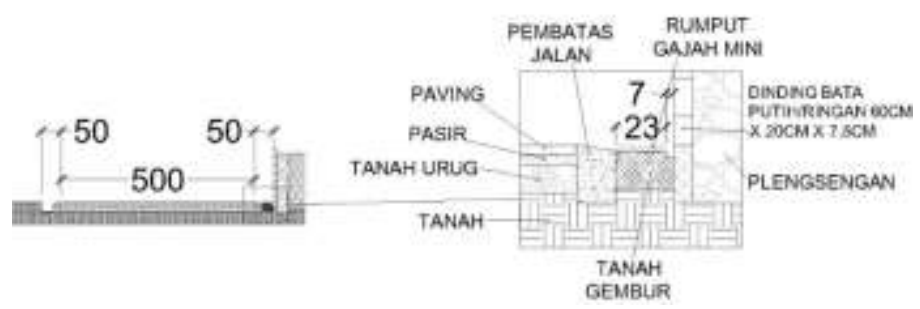

Gambar. 14

Potongan Selokan Yang Berfungsi Dengan Baik

Sumber: Ujianto, 2019

\section{a. Alternatif 1 Taman Pengarah}

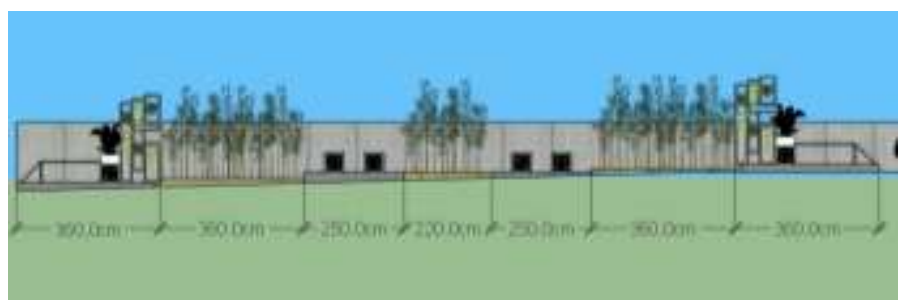

\section{Gambar. 15}

Detail Ukuran Pra-Desain Taman

Sumber: Ujianto, 2019

Kayu memang material yang selalu menarik perhatian dan menjadi bahan dasar pembagunan hunian selain batu bata dan semen. Kayu pun terdiri dari aneka macam jenis, salah satunya adalah kayu kamper.

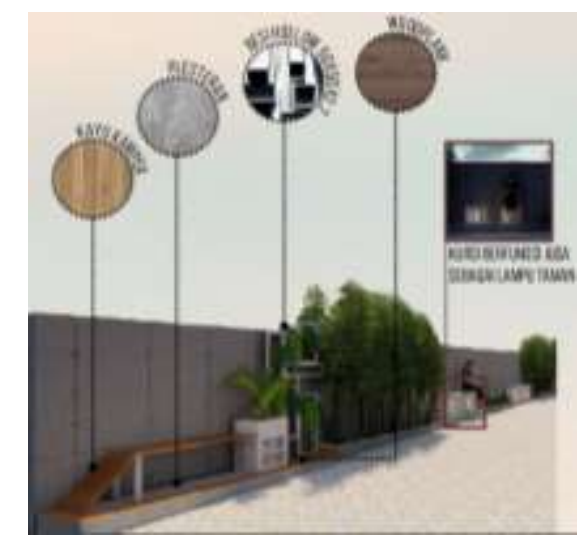

Gambar. 16

Penggunaan Material Pra-Desain Taman

Sumber: Ujianto, 2019 
Vertical garden di Indonesia juga sering disebut dengan taman dinding, green wall, vertical landscape, living wall, dan lain sebagainya. Secara sederhana, vertical garden berbeda dengan model taman horizontal yang kita kenal selama ini karena ditanam secara vertikal atau tegak lurus.

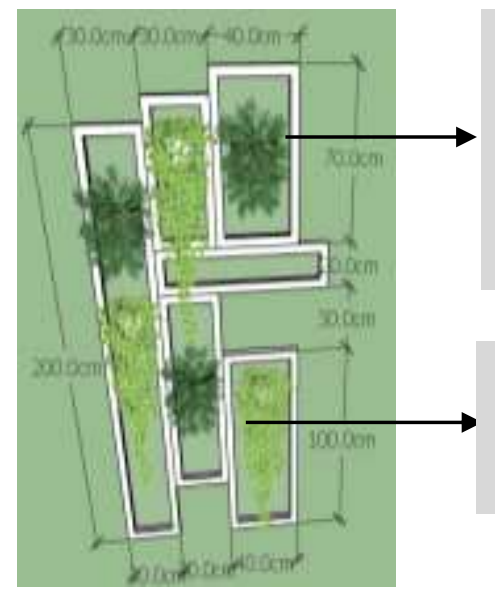

Frame dari bahan baja ringan berukuran sekitar $0,5 \times 1 \mathrm{~m}$ dan pasang ke tembok menggunakan baut atau perekat lainnya. Beri celah minimal $7 \mathrm{~cm}$ dari tembok, agar media tanam tidak langsung menempel ke tembok karena lembab dan bisa membuat tembok berlumut.

\section{Vertical Garden Pra-Desain Taman}

Sumber: Ujianto, 2019

Lampu taman pada kegiatan Pra-Desain taman ini menggunakan material roster beton. Roster beton tersebut di tata sedemikian rupa hingga berbentuk sebuah kubus yang didalamnya telah terpasang lampu, sehingga saat malam hari lampu tersebut mengeluarkan bias cahaya. Selain menambah estetika lampu ini juga dapat digunakan sebagai penerangan taman. Harganya pun cukup murah dan tahan lama lebih ekonomis dibandingkan bahan lain.
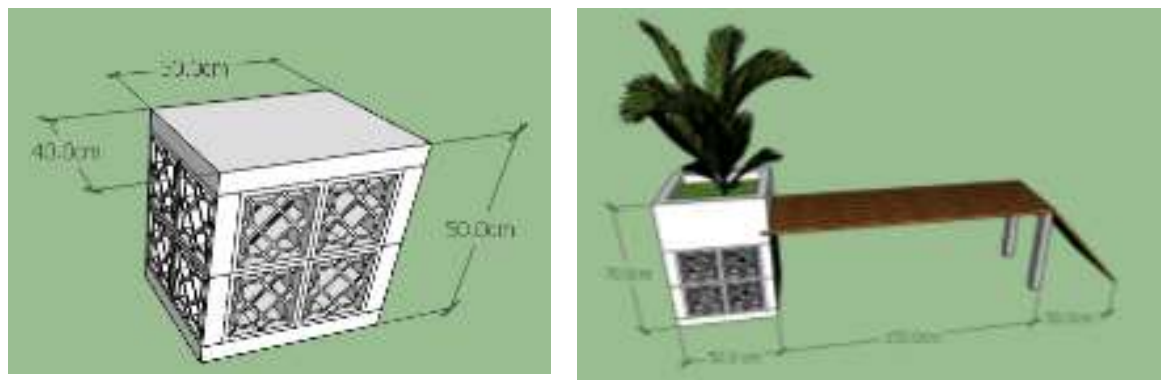

Gambar. 18

Lampu dan kursi Pra-Desain Taman

Sumber: Ujianto, 2019

PAWON: Jurnal Arsitektur, Nomor 01 Volume IV, Bulan Januari-Juni Tahun 2020, ISSN 2597-7636 


\section{b. Alternatif 2 Taman Pengarah}

Pada alternatif yang kedua ini terdapat 2 tempat vertical garden yaitu pada sisi kanan dan kiri. Vertical garden didesain dengan material kawat ayam untuk meletakkan pot gantung, dan dengan menggunakan bingkai besi hollow pada sisi pinggirnya.

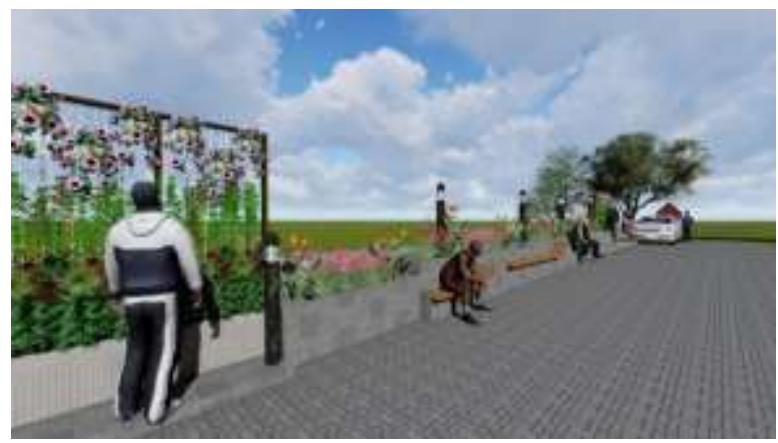

Gambar. 19

Alternatif Pra-Desain Taman

Sumber: Ujianto, 2019

Vertical garden pada alternatif ke-2 ini, menggunakan besi hollow sebagai bingkai dan ditengahnya yang kemudian dipasang kawat ayam sebagai media menempatkat pot gantung.

Sedangkan untuk tempat duduk taman menggunakan plat beton dengan rangka besi. Untuk menambah estetika taman, tempat tanaman menggunakan material batu bata dengan finishing batu alam / plester unfinishing (penyesuaian biaya)

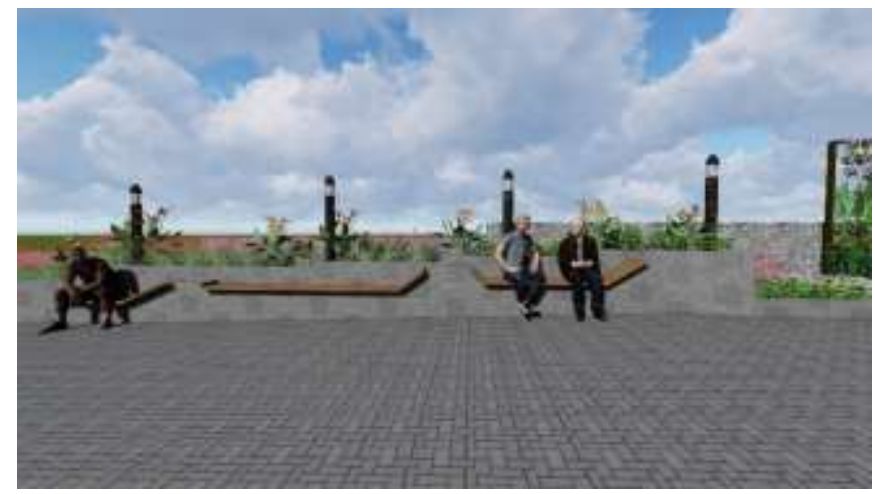

Gambar. 20

Kursi Taman Alternatif ke-2

Sumber: Ujianto, 2019

PAWON: Jurnal Arsitektur, Nomor 01 Volume IV, Bulan Januari-Juni Tahun 2020, ISSN 2597-7636 


\section{KESIMPULAN}

Kerjasama antar warga yang berupa diskusi tentang fasilitas umum apa saja yang dibutuhkan pada kompleks kavling Sidomamur ini, menjadikan dasar pemilihan fasilitas umum apa saja yang akan didesain dan diterapkan dengan baik pada kompleks kavling Sidomakmur Baru. Masalah yang muncul dalam perancangan fasilitas umum nantinya akan terselesaikan dengan baik, sehingga dapat bermanfaat bagi masyarakat khususnya warga kavling Sidomakmur Baru. Sehingga, desain atau rancangan yang nantinya akan diwujudkan mampu menjadikan fasum tersebut sebagai identitas wilayah di Kompleks Kavling Sidomakmur Baru.

\section{DAFTAR PUSTAKA}

Adrianto, Bowo, 2006, Persepsi Dan Partisipasi Masyarakat Terhadap Pembangunan Prasarana Dasar Permukiman Yang Bertumpu Pada Swadaya Masyarakat Di Kota Magelang. Semarang. Program Pascasarjana Magister Pembangunan Wilayah Dan Kota Universitas Diponegoro.

Adisasmita, Rahardji, 2010, Analisis Tata Ruang Pembangunan, Yogyakarta: Graha IImu.

Adi Prasetyo, Antonius. 2016. "Perencanaan Riset Pasar Pembuatan Vertical Garden Dengan Rangka Baja". Fakultas teknologi Industri. Universitas Atmajaya Yogyakarta.

Abdillah. (2006). Taman dan Hutan Kota. Jakarta : Azka Mulia Media.

Djamal Irwan, Zoer'aini, 2005, Tantangan Lingkungan dan Lansekap Hutan Kota, PT Bumi Aksara, Jakarta.

Follis, John. Architectural Signing and Graphics. London: The Architectural Press Ltd., 1979, hlm. 13.

Indrojarwo, Baroto Tavip. Design Study Of Standardization Of Street Name Signage For City Of Indoensia. Surabaya: Jurusan Desain Produk Industri, FTSP ITS. 2010, hlm. 3-4

Laurie, M. (1986). Pengantar kepada Arsitektur Pertamanan. Bandung: Intermatra

Supriyanto, Sugeng. Meraih Untung dari Spanduk hingga Billboard. Yogyakarta: Pustaka Grhatama. 2008, hlm. 55.

Shabrina Alfari. 2016. Vertical Garden, Solusi Taman untuk Keterbatasan Lahan. Jakarta. https://www.arsitag.com/article/vertical-garden-solusitaman-untuk-keterbatasan-lahan.

Kusrianto, Adi. Pengantar Tipografi. Jakarta: Elex Media Komputindo. 2010, hlm 23.

Koestoer H. R. 1997. Perspektif Lingkungan Desa - Kota. Jakarta Penerbit Universitas Indonesia. 